\title{
ANALISIS KELAYAKAN PENGEMBANGAN PROYEK CITRA GARDEN PURI SEMANAN CITRA GARDEN CITY
}

\author{
Anugrahenny Sekreningtyas \\ Program Studi Magister Manajemen Universitas Tarumanagara \\ henny.tyas@ciputra.co.id
}

\begin{abstract}
Jakarta is experiencing a tremendous residential growth due to the high level of urban migration to Indonesia's capital. Therefore, PT CD, through its subsidiary, PT CAP, tries to fulfill the increasing demand of residential housing by developing a 180,328 $\mathrm{m} 2$ of land in the West of Jakarta. The development is called the Citra Garden Puri project.

This paper is developed to determine the feasibility of the project through cash flow sensitivity analysis. There are 3 (three) assumptions used, which are : the normal, pessimistic, and optimistic assumptions. These assumptions are tested through 3 (three) calculation methods: Payback Period, Net Present Value (NPV), Internal Rate of Return (IRR), and Profitability Index (PI). The results of the sensitivity analysis are are Based on the Payback Period calculation, the project is deemed feasible. The current company's payback period is approximately 4 years, while the payback periods for the project are 24 months, 24 months, a for the normal, and optimistic assumptions consecutively. Based on the NPV calculation, the project is deemed feasible. The NPV is positive for all assumptions. Based on the IRR calculation, the project is deemed feasible. The IRR for the normal and optimistic assumptions are higher than the Weighted Average Cost of Capital (WACC). Therefore, based on the results of the sensitivity analysis of the project's cash flow, it is concluded that the Citra Garden Puri Semanan project is a profitable business decision. To increase profitability level, the company should try to find other financing alternatives to lower the cost of capital.
\end{abstract}

Abstract : Pertumbuhan penduduk yang pesat ke Jakarta karena pengaruh urbanisasi telah menyebabkan permintaan akan kebutuhan perumahan sebagai tempat tinggal juga meningkat. Situasi seperti ini yang ditangkap oleh PT CD sebagai ladang bisnis yang menjanjikan. Oleh karena itu PT CD melalui anak perusahaannya PT CAP mencoba mengembangkan suatu lahan kosong seluas 180,328 $\mathrm{m} 2$ di wilayah Jakarta Barat dan lahan ini diberi nama Citra Garden Puri Semanan.Untuk perumusan strategi dan keputusan yang benar, diperlukan analisis terhadap faktor faktor yang berpengaruh dalam perkembangan perusahaan baik internal maupun eksternal. Dan perlu dilakukan peninjauan dari sisi kesehatan CashFlow perusahaan untuk melakukan ekspansi. Selain itu dibuat semacam penelitian untuk mengetahui apakah pengembangan lahan ini menguntungkan atau tidak, dengan melakukan Analisis Kelayakan Bisnis. Analisis keputusan investasi dilakukan dengan melakukan uji sensitivity analisis, target penjualan dibuat menjadi 2 alternatif yaitu : alternatif Normal dan alternatif Optimis. Selanjutnya analisis keputusan investasi dilakukan dengan menggunakan 3 (tiga) metoda utama kalkulasi, yaitu Payback Period, NPV (Net Present Value), IRR (Internal Rate of Return) dan Profitability Index. Untuk studi kelayakan, pada umumnya keempat metoda tersebut sudah cukup kalau diterapkan pada hasil tabel CashFlow di atas, sebagai landasan untuk pengambilan keputusan investasiDari hasil penelitian yang telah dilakukan oleh penulis, diperoleh secara payback period didapat Alternatif Normal 24 bulan, alternatif Optimis 24 bulan. Hasil ini jauh lebih kecil dari ketetapan manajemen yang 4 tahun, dengan demikian proyek ini layak diterima. Analisis Net Present Value, Dari hasil perhitungan, NPV cash inflow masih jauh lebih besar dari pada NPV cash outflow artinya menurut penilaian NPV bahwa proyek ini dianggap sangat layak untuk dilaksanakan. Internal 
Rate of Return (IRR) proyek ini feasible karena yang kalau dicari IRR-nya alternatif normal dan alternatif optimis lebih besar dari Weighted average cost of capital (WACC)

Berdasarkan hasil analisis dan perhitungan yang telah dilakukan oleh penulis dalam kaitannya dengan proyek Pengembangan Perumahan Citra Garden Puri Semanan di wilayah Jakarta Barat, maka secara umum investasi tersebut dianggap sangat layak dan menguntungkan tidak hanya pihak developer tetapi juga konsumen yang membeli rumah di proyek tersebutMemperhatikan apa yang telah dianalisis dan dibahas, maka saran dari penulis adalah melakukan pengecekan kembali terhadap cashflow dengan mempertimbangan pencarian alternatif pendanaan dengan pinjaman yang ditingkatkan sehingga cost of capital kecil.

Keywords : Payback Period,NPV,IRR

\section{PENDAHULUAN}

Pertambahan penduduk yang sedemikian besar, mengakibatkan populasi di Jakarta semakin bertambah dan kebutuhan akan pemukiman / tempat tinggal menjadi meningkat dari tahun ketahun. Jakarta sangat diminati untuk menjadi tempat pemukiman dan perkantoran karena asumsi sebagian besar orang bahwa peluang bisnis terbesar adalah di Ibukota Jakarta. Walaupun harga jual perkantoran dan pemukiman di Jakarta sangat mahal dan lalu lintas Jakarta sangat macet namun tidak menjadi penghalang bagi yang ingin tinggal dan berbisnis di Ibukota Jakarta.

Sampai saat ini usaha di bidang property masih memiliki prospek yang cerah dan mendatangkan banyak keuntungan . Karena kondisi saat ini sangatlah meyakinkan bahwa usaha dibidang property memiliki daya tarik tersendiri bagi investor. Tetapi banyak juga pengusaha mengalami kebangkrutan. Kenyataan ini menyadarkan bahwa kondisi bisnis perumahan seperti juga usaha di bidang lainnya mengalami fluktuasi. Fluktuasi industri ini berkaitan dengan kondisi perekonomian masyarakat. Bisnis perumahan adalah bisnis yang terakhir menikmati kenaikan pertumbuhan ekonomi. Hal ini disebabkan karena produk perumahan dapat digolongkan kepada barang investasi, jadi tidak merupakan prioritas utama dalam pembelanjaan. Di sisi lain proses pengadaannyapun membutuhkan waktu yang lama.

Seiring dengan perbaikan-perbaikan yang di lakukan oleh pemerintah disegala bidang, perlahan membuat perekonomian Indonesia mulai jalan dan menggeliat lagi. Salah satu strategi yang menguntungkan bagi para investor dan konsumen adalah tingkat suku bunga yang rendah, sehingga masyarakat lebih suka memutar uang dari pada menyimpan di Bank. Kondisi seperti ini juga memberikan keuntungan bagi para pelaku bisnis di bidang perumahan yang menyebabkan permintaan akan rumah meningkat.

Karena permintaan yang meningkat inilah penulis dalam tesis ini ingin melakukan suatu analisis awal, dalam rangka pemenuhan kebutuhan akan perumahan, yang dapat membantu pengambilan keputusan investasi dibidang pengembangan atau pembangunan kawasan hunian kelas menengah keatas diwilayah Jakarta Barat.

Analisis awal ini adalah merupakan suatu studi kelayakan pengembangan kawasan yang menentukan apakah gagasan bisnis ini bisa dipertimbangkan dan layak untuk dilaksanakan. 


\section{Pokok Masalah}

Dalam tesis ini penulis akan mengulas mengenai strategi yang akan dilakukan oleh PT. CGC melalui anak perusahaannya PT. CAP dalam rangka pembukaan lahan baru seluas $\pm 18,7$ ha untuk pengembangan kawasan hunian beserta fasilitas pendukungnya di daerah Kalideres di Jakarta Barat sebagai wujud ekspansi perusahaan dalam pengembangan unit usahanya. Proyek lahan baru seluas 18,7 ha ini dinamakan proyek Citra Puri Semanan.

Dilihat dari kondisi lingkungan dimana lokasi projek berada dikelilingi oleh begitu banyak kompetitor, tentu akan menyebabkan adanya suatu rencana dan strategi pengembangan proyek yang matang dari PT. CAP dalam menghadapi persaingan di bisnis pengembangan properti.

Masalah yang akan dibahas dalam penulisan ini adalah:

- Bagaimana mengatur manajemen proyek dengan baik selama masa tahap pengembangan ( development) dan pertumbuhan ( growth)?

- Bagaimana melakukan analisis aspek pemasaran untuk menilai kemampuan konsumen ( buyer ) dalam menyerap produk perumahan yang ditawarkan dan kemampuan manajemen perusahaan dalam mendukung proses produksi pembangunan perumahan dan infrastrukturnya?

- Bagaimana menyusun analisis aspek keuangan (finansial), dalam hal ini menekankan pada aspek analisis arus kas dan analisis laporan keuangan pro-forma ?

\section{Landasan Teori}

Menurut Kasmir dan Jakfar (2010) studi kelayakan bisnis adalah suatu kegiatan yang mempelajari secara mendalam tentang suatu kegiatan atau usaha yang akan dijalankan,untuk menentukan layak atau tidaknya suatu bisnis dijalankan.

Dalam suatu perekonomian yang kompleks seperti sekarang ini, orang harus mau menghadapi tantangan dan risiko untuk mengkombinasikan tenaga kerja, material, modal dan manajemen secara baik sebelum memasarkan suatu produk. Sebuah rencana investasi seharusnya diawali dengan suatu evaluasi kelayakan terhadap rencana investasi itu. Sekalipun terdapat bukti bahwa ada pengusaha yang berhasil melaksanakan proyek secara menguntungkan tanpa didahului evaluasi kelayakan, dan pengusaha lainnya justru gagal mengoperasikan proyek yang sebelumnya sudah diadakan evaluasi kelayakan oleh tim yang andal, namun evaluasi tersebut tetap penting artinya. Dari sudut perspektif rasional-objektif, tidaklah patut melakukan sesuatu yang mempunyai resiko yang besar berdasarkan persepsi untung-untungan. Investasi yang memiliki resiko besar seharusnya didahului oleh suatu studi kelayakan.

Dengan demikian studi kelayakan suatu bisnis merupakan penelitian tentang dapat tidaknya suatu bisnis (biasanya merupakan proyek investasi) dilaksanakan dengan berhasil. Suad Husnan, Suwarsono(2000). Pengertian keberhasilan ini mungkin bisa ditafsirkan berbedabeda. Ada yang menafsirkan dalam artian yang terbatas, terutama dipergunakan oleh pihak swasta yang lebih berminat tentang manfaat ekonomis suatu investasi. Sedangkan dalam artian luas dapat dilihat atau dipertimbangkan berbagai faktor seperti manfaat bagi masyarakat luas yang bisa berwujud penyerapan tenaga kerja, pemanfaatan sumber daya yang melimpah dan sebagainya.

Pada proyek komersial, tumpuannya terletak pada kemampuan untuk memasarkan produk yang dihasilkan ke pasar yang telah direncanakan. Keberhasilan menjual produk yang dihasilkan menjadi wahana untuk menerima dana berupa arus kas masuk dari hasil penjualan. Dana hasil penjualan dimaksud berguna untuk memikul beban pengeluaran, sekaligus menghasilkan laba. Apabila salah satu, atau beberapa pasar mengalami perubahan, dan daya 
serap pasar terhadap produk yang dijual menurun, maka perusahaan akan menghadapi kesulitan dalam merealisasikan target arus kas masuk yang telah direncanakan. Selanjutnya, kejadian itu akan mengganggu operasi, bahkan mengancam terhentinya operasi perusahaan. Jika kenyataan tersebut dihadapi setelah proyek dilaksanakan, maka investor tidak mudah untuk menghentikan dan mengalihkan dana ke proyek lainnya. Hal itu antara lain disebabkan oleh sulitnya mengubah komitmen keuangan yang telah dibuat dengan pihak kreditur atau penyandang dana. Dengan demikian, keterlanjuran melakukan investasi yang belum dijamin keakuratan evaluasinya, berpotensi sangat menyulitkan di masa mendatang.

Memperhatikan uraian yang telah dikemukakan di atas, dapat disimpulkan beberapa kegunaan primer dari studi kelayakan. Suad Husnan, Suwarsono (2000) , yakni :

- Memandu pemilik dana untuk mengoptimalkan dana yang dimilikinya.

- Memperkecil resiko kegagalan investasi, dan pada saat yang sama memperbesar peluang keberhasilan investasi yang bersangkutan.

- Alternatif investasi teridentifikasi secara objektif dan teruji secara kuantitatif sehingga manajer puncak mudah mengambil keputusan investasi yang objektif.

- Aspek terkait terungkap secara keseluruhan dan lengkap, sehingga penerimaan dan atau penolakan terhadap alternatif investasi didasarkan atas pertimbangan terhadap semua aspek proyek dan bukan hanya aspek finansial saja.

Dengan melihat hasil perhitungan diatas, maka pengembangan proyek Citra Garden Puri Semanan dianggap layak (feasible). Namun demikian untuk lebih memberikan keyakinan terhadap analisis investasi ini, maka selanjutnya penulis akan melakukan perhitungan payback period, net present value, Internal Rate of Return (IRR) .

\section{ANALISIS}

Metode pemulihan investasi (payback period method) adalah suatu periode yang diperlukan untuk menutup kembali pengeluaran investasi (initial cash investment) dengan menggunakan aliran kas. Jadi payback periode merupakan rasio antara initial cash investment dengan cash inflow-nya yang hasilnya merupakan satuan waktu. Jangka waktu pemulihan modal adalah jangka waktu yang diperlukan untuk mengembalikan seluruh modal yang diinvestasikan.

Dalam analisis ini, yang diperhitungkan adalah rasio antara initial cash investment/cash outflow dengan cash inflow, yang hasilnya merupakan satuan waktu. Selanjutnya rasio ini dibandingkan dengan maximum payback period yang telah ditetapkan oleh PT CAP yaitu selama pembangunan proyek atau sampai pada penjualan seluruh produk (lahan dan bangunan), yang dalam hal ini ditetapkan selama 4 tahun. Kaidah yang digunakan dalam pengambilan keputusan pada metode ini adalah apabila payback period yang didapat dari hasil perhitungan lebih kecil dari pada waktu yang telah ditentukan oleh manajemen perusahaan (4 tahun) maka investasi ini dianggap layak.

Pada proyek Pengembangan Perumahan Citra Garden Puri ini modal awal (initial cash investment)-nya adalah 30 Milyar yang dikucurkan dari modal sendiri. Untuk mengetahui berapa lama waktu yang dibutuhkan untuk mengembalikan initial cash investment yang 30 Milyar tersebut dapat dilihat melalui tabel Cash Flow bahwa nilai $30 \mathrm{M}$ dapat dikembalikan dalam waktu 2 tahun baik dalam skenario normal maupun Optimis jadin dapat disimpilkan proyek ini layak dijalankan.

Dengan perhitungan di atas, berarti payback period untuk Alternatif 1 Normal ini adalah 24 bulan, untuk Alternatif 2 Optimis adalah 12 bulan. Semua hasil ini jauh lebih kecil dari ketetapan manajemen yang 4 tahun, dengan demikian proyek ini layak diterima. Tetapi metode payback periode ini sangat sederhana sehingga mempunyai kelemahan. Kelemahan 
utamanya yaitu metode ini tidak memperhatikan konsep nilai waktu dari uang disamping juga tidak memperhatikan aliran kas masuk setelah payback. Jadi umumnya metode ini digunakan sebagai pendukung metode lain yang lebih baik.

Net Present Value (NPV)

Untuk menghitung NPV pada proyek ini, penulis menggunakan asumsi-asumsi sebagai berikut :

- Tingkat bunga yang diperoleh dari Bank sebesar 7\%, dan tingkat bunga Kebijakan pemegang saham terhadap modal sendiri sebesar $15 \%$ maka Weighted Average Cost Of Capital (WACC) yang ditetapkan pada perhitungan NPV sebesar $15 \%$ karena proyek ini $100 \%$ menggunakan modal sendiri (tabel cash revenue)

Dari tabel revenuediatas, terlihat bahwa NPV cash inflow masih jauh lebih besar dari pada NPV cash outflow yaitu dengan selisih sebesar

- Alternatif 1 Normal = Rp. 134.276.000.000,-

- Alternatif 2 Optimis $=\quad R p .130 .000 .000 .000,-$

Artinya menurut penilaian NPV bahwa proyek ini dianggap cukup layak untuk dilaksanakan dengan alternatif terbaik adalah skenario normal dikarenakan akan ada kenaikan harga jual.

Internal Rate of Return (IRR)

Metode ini digunakan untuk mencari tingkat bunga yang menyamakan nilai sekarang dari arus kas yang diharapkan di masa datang, atau penerimaan kas, dengan mengeluarkan investasi awal.

Dari hasil nett cashflow yang ada didapat IRR sebesar :

- Alternatif 1 Normal $=\quad 89 \%$

- Alternatif 2 Optimis $=\quad 96 \%$

IRR alternatif 1 dan 2 lebih besar dari Weighted Average Cost Of Capital (WACC), sehingga layak dilaksanakan

Dari beberapa analisis penilaian investasi dengan perhitungan Payback Periode, Net Present Value, Internal Rate of Return dan Profitability Index, kesemuanya menunjukkan bahwa investasi PT CAP dalam rangka Pengembangan Perumahan Citra Garden Puri di wilayah Jakarta Barat ini dianggap sangat layak untuk dilaksanakan.

Saran

Memperhatikan apa yang telah dianalisis dan dibahas sebelumnya, maka saran-saran yang dapat diberikan dalam tulisan ini adalah sebagai berikut :

- Dari aspek marketing perlu melakukan "market survey" secara lebih tajam lagi untuk menentukan positioning proyek dan target market serta pengembangan detail product sales yang sesuai dengan kawasan. Pelaksanaan Market Positioning tersebut dijalankan melalui :

$>$ Identifikasi keunggulan kompetitif yang memberikan nilai tambah terbesar dengan cara mengadakan : difrensiasi produk, difrensiasi jasa, difrensiasi personil dan difrensiasi citra.

$>$ Memilih keunggulan kompetitif yang tepat, antara lain dengan mempromosikan apa saja perbedaan yang dimiliki.

Mewujudkan dan mengkomunikasikan posisi yang dipilih.

$>$ Menggunakan keempat macam sarana promosi yang adalah :

Periklanan (Advertising)

Promosi penjualan (Sales Promotion)

Publisitas (Publicity) 
Penjualan kedaerah-daerah (Road Show)

- Dari aspek teknik, harus mampu memberikan nilai tambah pada produk bangunan yang dihasilkannya, baik mengenai satuan harga dan alternatif spesifikasi material yang digunakan maupun dari sisi metodologi dan kualitas pengawasan dari pekerjaan konstruksi bangunan rumah, pematangan lahan maupun prasarana lingkungan, karena kualitas bangunan dan prasarana lingkungan yang baik dapat meningkatkan nilai jual kawasan tersebut .

- Dari aspek keuangan, melakukan pengecekan kembali terhadap cashflow yang sudah dibuat disesuaikan dengan strategi pemasaran, pencarian alternatif pendanaan dan monitoring efisiensi pengeluaran biaya-biaya yang muncul selama proyek berjalan.

\section{DAFTAR PUSTAKA}

Adisetiawan, R. (2012). Analisis Pengaruh Kinerja Keuangan dalam Memprediksi Pertumbuhan Laba. Jurnal Aplikasi Manajemen, Vol10 No 3, 669-681. ISSN: 16935241. Terakreditasi SK DIRJEN DIKTI NO. 66b/DIKTI/KEP/2011.

Hatta, Atika Jauhari. (2002). Faktor-Faktor yang Mempengaruhi Kebijakan Dividen: Investigasi Pengaruh Teori Stakeholder. JAAI Volume 6 No. 2

Kartini dan Arianto, Tulus. (2008). Struktur Kepemilikan, Profitabilitas, Pertumbuhan Aktiva dan Ukuran Perusahaan terhadap Struktur Modal pada Perusahaan Manufaktur. Jurnal Keuangan dan Perbankan Vol. 12, No 1, 11-21.Terakreditasi SK. No. 167/DIKTI/Kep/2007.

Munawir. (2010). Analisa Laporan Keuangan. Yogyakarta : Liberty

Prasetyo, Aries Heru. Manajemen Keuangan bagi Manajer Non Keuangan. Jakarta: PPM, 2011

Putrakrisnanda. (2009). Faktor-Faktor yang mempengaruhi Struktur Modal Perusahaan Manufaktur di Indonesia.

Riyanto, Bambang. (2001). Dasar-dasar Pembelanjaan. Edisi Keempat. Yogyakarta: Penerbit Universitas Gajah Mada.

Sarwono, Jonathan. (2016). Prosedur-Prosedur Analisis Populer Aplikasi Riset Skripsi dan Tesis dengan Eviews. Bandung: Gava Media

Sawir, Agnes. (2005). Analisis Kinerja Keuangan dan Perencanaan Keuangan Perusahaan. Jakarta: PT Gramedia Pustaka Utama.

Sutanto, J.E and Pribadi, Yanuar. (2012). Efficiency of Working Capital on Company Profitability in Generating ROA. Journal of Eonomics, Business, and Accountancy Ventura, Vol 15 No 2, 289-304. ISSN 2087-3735.Accreditation No 110/DIKTI/Kep/2009.

Swasta, Basu., \& Handoko, Hani. (2001). Manajemen Penjualan. Yogyakarta: Badan Penerbit Fakultas Ekonomi.

Syamsuddin, Lukman. (2007). Manajemen Keuangan Perusahaan. Jakarta: PT Rajagrafindo Persada. 
